\title{
11. "Stay on Your Path, Young Man"
}

\section{PAUL GRIMSTAD}

Almost ten years ago I participated in the conference whose proceedings would become the volume Stanley Cavell and Literary Studies: Consequences of Skepticism. ${ }^{1}$ Stanley sat directly in front of me and listened attentively to my talk, thrilling and scary, not to say awkward, reading out "Cavell writes..." and "Cavell says..." with the man right there. After the Q and A, someone, I don't remember who, brought me over and introduced us. Stanley shook my hand and with the other patted my shoulder and said, with a broad smile, "Stay on your path, young man."

That brief introduction at the Barker Center led to an email exchange and to Stanley's invitation some months later to have lunch at a Japanese restaurant near his home in Brookline. I read The World Viewed on the train up from New York and planned to ask him things about that great and strange book, but we didn't talk about his work, or the paper I'd read, or about literature or philosophy at all. We spent two hours talking about how George Gershwin had merged Ravel-style orchestration with ragtime rhythms, Ben Webster's tenor saxophone playing with Duke Ellington in the 1940s, agreed there was a hint of Sarah Vaughan's vocal phrasing in Miles Davis' solos and, eventually, talked more generally of the implications of jazz improvisation for American democracy (among other things). It was great to be in a music nerd conversation with someone whose knowledge of jazz was intimidatingly vast (greater than my own anyway), yet utterly personal and without a shred of snobbery.

After lunch he invited me over to his home a few blocks from the restaurant. I played the piano (I remember picking out a certain Bill Evans chord voicing which Stanley seemed to appreciate) and then we went a couple floors upstairs to his writing studio. There were stacks of papers and books and a broad table where, I assu-

\footnotetext{
1. Richard Eldridge and Bernie Rhie, eds., Stanley Cavell and Literary Studies: Consequences of Skepticism (New York: Bloomsbury, 2011). My chapter is entitled "Emerson Discomposed: Skepticism, Naturalism, and the Search for Criteria in 'Experience'," 163-76.
} 
med, much of the writing I'd admired had been put together. I was struck by the quotidian plainness of these objects. It was like peeking behind a curtain to see that what one had previously taken to be a mysterious lab where things like Pursuits of Happiness or part four of The Claim of Reason had been cooked up, was just a site of humble daily work. Mostly I was struck that day by Stanley's endless generosity.

Stanley was, I think, temperamentally incapable of conformism. It made sense that he was eventually drawn to Emerson, who says "self-reliance" is the aversion to conformity. That idea is central to Cavell's moral understanding of human existence (what he sometimes called moral perfectionism) and also with what he called a "lifelong quarrel with the profession of philosophy.”2 And yet Stanley did want to make the study of something as idiosyncratic as the Essays or the Philosophical Investigations a professional activity. Emerson and Wittgenstein, so different from each other in so many ways, both had a wrenching and dramatic agon with institutional forms of thinking, which in many ways force one to contort one's mind to fit either brute bureaucratic and managerial protocols or conform to the group consensus (hence the infinite value of eccentricity, oddity, independence); crises of vocation which they worked out in their writing. Stanley did this too and he did it courageously and honestly.

There could be something whimsical, even perverse, in his nonconformism. In the memoir, Little Did I Know: Excerpts from Memory, Stanley notes the "pleasurable indecorousness" he felt in assigning films for philosophy seminars when no one else was doing that (I can't imagine Quine having his students watch Bringing Up Baby).3 I always loved "Being Odd, Getting Even," that fascinating essay about how the sound of Poe's prose-Stanley says it has a "perverse brilliance"-imitates, or uncannily copies, the sound of philosophical argument. 4 It wasn't that Stanley didn't have a taste for logic. In everything he wrote there are arguments, and his prose, like that of late Henry James, always has a glowing thread of coherence running through it, even at its most serpentine and prolix. The sentences "follow" from one another, as the logician might put it. That thread of coherence isn't just about logic; it also has to

2. Cavell, "The Politics of Interpretation (Politics as Opposed to What?)," in Themes Out of School: Effects and Causes (San Francisco: North Point Press, 1981), 31.

3. Cavell, Little Did I Know: Excerpts from Memory (Stanford, CA: Stanford University Press, 2010), 424.

4. Cavell, "Being Odd, Getting Even (Descartes, Emerson, Poe)," in Emerson's Transcendental Etudes, ed. David Justin Hodge (Stanford, CA: Stanford University Press, 2003), 99. 
do with having an ear. Elsewhere in the memoir, he notes how his mother had perfect pitch and a preternaturally attuned sight-reading ability. Stanley the writer had some of that.

Relatedly, he was good at telling stories, a talent he explicitly associates with his father. One of my favorites involves Cavell's esteemed teacher, J. L. Austin, in Cambridge, Massachusetts to give the William James lectures in 1955 (and which eventually became How to Do Things With Words). Stanley remembered Austin agreeing to join a pickup baseball game, even though Austin didn't really know the rules. After having a look over the diamond, he grasped the basics, tossed his jacket on the ground, stood stiffly in the batter's box (in tie and cufflinks) and whacked the first pitch he saw over the second baseman's head into the opposite field. When he got to first, Austin-and this is my favorite part-touched the base with his hand and rounded toward second. It could almost be an example out of late Wittgenstein: who is to say that just because every other time you've seen someone get to first after a hit they landed on the base with their foot, you're not free to touch it with your hand? Nothing in the rules of baseball explicitly prohibits it (you are also free to toss the tennis ball three-hundred feet in the air when you serve, see Philosophical Investigations §68). Cavell ends the story by noting how fast Austin ran around the bases and remembered the expression on his face when he got in safely at second with a double. A slight, satisfied grin.

Unless you count the afternoon in the Japanese restaurant and the Brookline brownstone, I never had Cavell as a teacher. Yet it is easy to infer from hearing audio of lectures or interviews, or hearing others remember the classes they'd taken with him, that he was an enormously gifted teacher. From the memoir: "lecturing to these groups over the years [I felt] I was in each case facing a sample of young fellow citizens of mine to whom anything could be said that I found it worth saying and felt that aspirants to democracy should gladly hear, on the condition that I took pains sufficient to say it, as talent allowed, lucidly and provocatively."5 Good description of teaching! Similar ideas might be imagined coming from John Dewey (Cavell's relationship with American pragmatism was interestingly fraught, I suspect in part because graduate students of his generation were force fed Experience and Nature). It's the

5. Cavell, Little Did I Know, 425. 
sound of someone paying attention, someone who cares. Students are rarely immune to that sound. They pick up on it as if tuning in to a certain frequency.

Stanley also had a good definition of writing: taking oneself by surprise. Looking for and elaborating upon the surprises generated in composition, building worlds of ideas or arguments or sounds (patterns of any kind, really) from out of those surprises, finding exhilaration and freedom in the process itself. All of that is as close to a "path" as I've ever been able to find. I didn't even know that that, all by itself, could be a path! 